\title{
Bambusa balcooa Roxb: A farmer's species of choice in Assam
}

\author{
Ritashree Khanikar
}

\author{
Rain Forest Research Institute, \\ Jorhat, Assam, India
}

\begin{abstract}
North-East India is considered as the high potential area of bamboos where occurrences of 90 species of bamboos are recorded. Among them 41 species are reported as endemic to that region. Northeast Indian states are also called as "Bamboo Queen of India". The bamboo also called poor man's timber is one of the most countable forestry species which play an important role in biodiversity conservation and climate control. Assam is very rich in forest tree resources including various species of bamboo and cane. It plays a vital part in lifestyle and rural economy of Assam. Forests of Dima Hasao and Karbi Anglong, Nagaon and North Lakhimpur districts can be specially mentioned. The important species of bamboo of economic value are the Bhaluka bamboo (bambusa balcooa), Jati bamboo (Bambusa tulda), Muli (Melocanna bambusoides), Dalu (Teinostachyum dalloa), Khang (Dendrocalmus longispatnus), Kaligoda (Oxytenanthera nigrociliata) and Pecha (Dendrocalamus Hamiltonii). Bambusa balcooa species is most commercially viable species under genus Bambusa due to its thickest and largest robust culms commonly used in construction purposes of house, other frame works and in making of agricultural implements, baskets, bridges and also for making paper. The article discusses in brief about the most economically viable species Bambusa balcooa under genus Bambusa.
\end{abstract}

Key Words:Economic, commercial, construction, pillars

\section{Taxonomic classification}

King Dom: Plantae

Family: Poaceae

Order:Poales

Tribe: Bambuseae

Subtribe: Bambusinae

Genus: Bambusa

Species :Bambusabalcooa

Chromosome number: $2 n=70$, aneuploid (Sobita Devi \& Sharma 1993).
Synonym: Dendrocalamus balcooa (Roxb.) Voigt (1845).

Local name

Bhaluka (Assam and Arunachal Pradesh

Baruwa (Manipuri)

Wamnah/Beru (Meghalaya)

Dhanu Bans/Bhalu Bans (Sikkim)

Barak (Tripura)

Bhalu bans (Nagaland)

\section{Significance of study}

Assam is said as the gateway of North-Eastern Region having geographical area is 78,438 km2. According to the FSI report 2015 forest area of the state is $26,832 \mathrm{~km} 2$ which covers $34.21 \%$ of its geographical area. Among which bamboo bearing area forests of is 7, $238 \mathrm{~km} 2$ (FSI, 2011). Bambusa balcooa is one of the most economically important bamboo of Assam, which belongs to sympodial bamboo, culms are densly tufted. It is considered as one of the best and strongest bamboo used for construction and building purposes. Hence there is an immense potential of commercial cultivation of this species for both industrial and domestic use.

\section{Morphology of Bambusa balcooa Roxb}

Culms: Culms of Bambusa balcooa are 15-25 m height and $8-16 \mathrm{~cm}$ in diameter. Tender culms are green and at maturity colour changes to dull grayishgreen. Walls are about $\pm 3.5 \mathrm{~cm}$ thick at basal portion. Length of internodes is different based on their position. Lower internodes are short $(10-12 \mathrm{~cm})$ as compared to the upper internodes $(40-45 \mathrm{~cm})$. In upper internodes cavities are larger than the lower internodes hairy (Barooah et.al, 2003).

Culm-sheath: In Bambusa balcooa two kinds of culm-sheaths are found. Culm- sheaths of lower internodes are shorter and broader with densely appressed dark hairs on outer surface then the culm sheaths of upper internodes. (Barooah et.al, 2003). 
Leaves: Leaves are oblong-lanceolate, main vein prominent, margins scabrous-ciliate, leaf-sheaths striate, ligule membranous and broadly triangular. hairy .(Barooah et.al ,2003)

Flower: Inflorescence is large compound panicle, spikelets ovoid, lanceolate, flattened, empty glumes ovate-acute, many nerved, palea as long as flowering glumes, stamens hardly exerted, anthers glabrous, ovary broadly ovoid, acuminate and hairy (Barooah et.al ,2003)

\section{Key Identifying characters}

Ventral surface of the leaf blades green or without white crust. Culms strong, walls thick; culm-sheaths large, longer than broad, covered with some patches of appressed hairs on outside, auricles usually small. It is resembles $B$. bamboos in its lower leafless, stout branching appearance and thick clump formation, but is readily distinguished by glabrous culm-sheath blade, longer and broader leaves and branch lets with unarmed nodes (Borooah et al, 2003). Basal internodes are very short, nodes are swollen, presence of brown hairs at the lower nodal portion, Branches is swollen at base, at the base of the culm adventitious roots are present. Young shoots are dome shaped at the tip. At the nodal ring of the young culm white rings are presents. Culm sheath auricle very short or abscent (Tripathi Y.C 2008) .The plant has multipurpose utility and sometimes referred as "Female Bamboo".

\section{Introduction}

Bambusa balcooa Roxb.is indigenous to Assam, Bangladesh, India, Laos, Myanmar, Nepal and Vietnam where it is frequently cultivated. This bamboo species is also introduced and cultivated in many other countries of South-East and East Asia, and in tropical Africa and Australia. In Assam the species is found throughout the state. The plant grows well in tropical low lands with temperature $22-28^{0} \mathrm{C}$.

The plant grows well in tropical to warm temperate climatic conditions. It can be found at altitude up to 600 meters (http:// proseanet.org). Mean annual rainfall should be in the range 2,300-3,000 $\mathrm{mm}$. Soil $\mathrm{pH}$ should be 5-6 but can grow from 4.5-7.5 range (http://ecocrop.fao.org/ecocrop/srv/en/home).Well drained sandy loam to clay loam soil with $\mathrm{pH} 4.5$ to 6.0 is suitable for cultivation.

During the rainy season new shoots of bambusa balcooa are coming out and attain full culm length within 2-3 months and become mature within 4 years.

\section{Phenology}

Flowering of this species is rare. At the beginning of the nineteenth century Blatter (1930) remarked that Roxbutgh had reported the flowering of $B$ balcooa for the first time. Gamble 1896 reported that that the species flowered in Purnea districts of Bihar in 1849, Goalpara Assam in 1876, Kamrup, Assam in 1889 and Gorakpur (Uttar Pradesh) in 1881. Gregarious flowering of this species in 1986 was reported by Rawat, 1987. In North East Sporadic flowering was recorded at Khoraghat village under Bilasipara sub division of Dhubri district in March 1998 (Barooah, 1999). Sethalakshmi and Kumar, 1998 suggests the flowering cycle of the species as: $35-45( \pm 5)$ years.

\section{Propagation}

Bambusa balcooa can be propagated either by seed or by vegetative means. But availability of seed is rare. The commonly practiced vegetative propagation is propagation by cuttings from culm, branches or rhizome. Propagation through seed also difficult due to low viability, poor storage characteristics.

\section{Selection of materials}

Culms should be selected in their second year of growth. Physiological details should be study before collecting the propagating material to avoid flowering and death soon after propagation (Banik 1985) Leafy branches were not available in the first year growth culmps and thus they are unable to reserve sufficient nutrient. Culms which have strong central branches can be considered as best.

Cutting should be taken mainly in spring season, when there is abundant moisture in soil. It is necessary to watch the bud carefully and cuttings should be collected carefully observing the buds getting reading to burst. The collection time of cuttings may differ depending on the species and locality.

\section{Preparation of cuttings}

The suitable time for planting of cutting is Mid March to May. Segments are selected from the lower to mid zone of the culm and upper part is discarded along with the lateral branches of the upper culm. The selected segments should be pruned to a length of $10-30 \mathrm{~cm}$ depending on the presence of the healthy nods.

\section{Preparation of nursery bed}

The nursery bed should provide proper shade to maintain the dampness of soil. Soil of the nursery bed should has capacity to retain high moisture. There should be good drainage facility to prevent water logging. 


\section{Placing of cuttings in the bed}

Culm cuttings are placed horizontally keeping space of $30 \mathrm{~cm}$ between each culm at $6 \mathrm{~cm}$ dip from the top layer. Then the culms are covered with fine sand. The nursery bed is kept in moist condition under partial shade.

\section{Fertilization and management of the established clumps}

Dry farm yard manure or vermicompost should be applied depending on the fertility status of soil. Proper irrigation should be done for the first two years up to healthy establishment of the culm.

\section{Major pest}

The major pest of Bambusa balcooa are reported as Aphrophore sp. (Nymphs), Ceratovacuna silvestrii (Aphid), Crocidophora sp., Parasa sp., Psara licarsisalis, Pyrausta coclesalis walker in Assam by Raja Rishi et al., 2014.

\section{Agroforestry with $B$ balcooa}

$B$ balcooa is an value dcomponent of rural landscape and it contribute greatly to increase productivity and sustainability. This species is very well suited for agroforestry (Tiwari et al 2015) .Multiplication of bamboo from offsets takes four to five years to get yield first harvest. But when multiplication is raised through seedlings then it takes seven years to get the first yield. Balaji, 1991 reported a wide scope of bamboo as a component of agroforestry because of the uncertain weather conditions and increasing labour cost. Properly managed bamboo can be a suitable component to be grown in agri-silviculture, silvipastoral, agri-silvipastoral and agri silvi horticultural systems.

$B$ balcooa is most common species in home gardens of the farmers in Assam. Crops like banana, beetlenut, coconut, neem, bael, citrus, kathal etc are grown in combination with this species. Under agrisilviculture system, soyabean, niger, mustard, wheat, arahar are some of the important component at initial stage of growing. Banik, 1997 reported that, raising of shade tolerant crops such as pineapple, ginger, turmeric shade tolerant variety of sweet potato, etc is economically viable with bamboo.

\section{Culm age determination and harvesting}

Harvesting of 3-4 year old culm is proper. Young tender shoots should be harvested within 3 weeks after emergence about 25-35 cm length. Harvesting of culms should be carried out at non rainy season when copious culm production occurs. To use as raw material for construction determination of culm age is important. The culm age determination should be done observing the presence of culm sheath, initiation of bud on the culm node, initiation of branch, colour of culm, presence of ring and hair.

At the first year of age the culm sheath is present at 2-3 basal nodes of culm. Branching bud on the culm nodes breaks and thick stout branch are coming out. One year old culm possesses brown to whitish pubescent ring on the basal 6-9 nodes. At this age prominent and ridged nodes are observed. At the second year culm sheaths are usually absent or may present on 1-2 basal nodes. All the buds of the culm nodes at 4-5 basal nodes develop thick stout branches. Transformation of axillary branches into curved thorn like structure up to 5-6 basal nodes are take place. Basal 3-4 nodes have brown to whitish ring with adventitious roots. When the culm becomes 3 year old culm sheaths are absent. Dying of the bud on the basal 3-5 culm nodes occurred. At the basal 23 nodes of the culm dead adventitious roots ring may observe. At the four year old culm also culm sheaths absent and less number of leaves are observed. Axillary and secondary branches transform into curve thorn like structure. Basal nodes are stout and thick. (Banik, R.L, 2000)

\section{Uses}

Bambusa balcooa has tremendous economic, commercial and local importance. It provides major raw materials for construction of houses, for construction of pillars and walls. $B$ balcooa is commonly used for pillars. It is a useful raw material in construction industry. The species shows drought resistant capacity hence it can grow in low rainfall areas. The species is also listed as most suitable edible species. The plant is also used in production of different bamboo based products like charcoal, panels, flooring, pulp, daily used articles etc. (Pandey et al. 2012).

It is one of the preferred species as non-wood forest fibre source due to its mechanical strength, high specific gravity and long fibers (Amita $\mathrm{Pal}$ et. $\mathrm{Al}$ 2010)

Some farm devices namely Huja, Bang,Ukonetc are made from $B$ balcooa which are some traditional device use to carry bunches of rice, to carry rice in basket, to reshuffle the rice straw during and after raping of rice bunches. Normally $B$ balcooa is used to prepare almost all agricultural products. Some of the other products like stool (Murha) is made from this species.

Soft juvenile bamboo shoots of Bambusa balcooa are popular as food by all tribes and ethnic groups of the region. These bamboo shoots have medicinal 
properties preventing cardiovascular diseases, cancer and weight loss to improve digestion. This is also considered as heart protective vegetables. Singh KA (2002) reported that trade of bamboo pickle in a tourist spot on Nogpoh (Meghalaya) is estimated to be $1,170 \mathrm{~kg}$ to $2210 \mathrm{~kg}$ annually. Bhagwati S, Deka BC (2004) found B. Balcooa is better species for pickle making among all the other species of this region.

\section{Conclusions}

Bambusa balcooa is identified as commercially important edible bamboo species by National Mission on Bamboo Application (NMBA). Hence the species has great importance as edible species as well as raw material for house hold construction and in making of different agricultural tools. The species is mainly cultivated in homestead gardens and emphasis on commercial cultivation of the species executes economic growth of the rural village people of Assam.

\section{References:}

[1] Amita Pal., Jayadri Sekhar Ghosh, Malay Das and Samik Bhattacharya Identification of Superior Fiber-Trait-Yielding Genetic Resources of Bambusa balcooa: Analysis of PhysicoChemical Properties of Fibers. VIII World Bamboo Congress Proceedings. Vol 9-5, 2008.

[2] Balaji. S.. Agroforestry for prosperity. Forest News, 1(3): 9-11, 1991

[3] Banik, R. Techniques of bamboo propagation with special reference to pre-rooted and pre-rhizomed branch cuttings and tissue culture. In A. R. Rao, G. Dhanrajan, C. B. Sastry (ed.), Recent Research on Bamboos (pp. 160169), 1985.

[4] Banik, R.L. Growth response of bamboo seedlings under different light conditions at nursery stage. Bangladesh Journal of Forest Science, 26 (2): 13-18, 1997.

[5] Banik, R.L. Silvivulture and field guide to priority bamboos of Bangladesh and South Asia: 30-32, 2000.

[6] Barooah C and S. K. Borthakur, "Diversity and Distribution of Bamboos in Assam" ISBN 10:8121102308, Bishen Singh Mahendra Pal Singh, Dehradun, 2003.
[7] Barooah C, Flowering of Bamboos in Assam. Indian Forester, 125:760-761, 1999.

[8] Bhagwati S, Deka BC Screening of bamboo species for pickle production. Indian Food Packer 49-53, 2004.

[9] Blatter E, The flowering of bamboos Part I, Bombey Natural History Society, 33:899921,1930.

[10] FSI (Forest Survey of India), The India State of Forest Report 2011.

[11] FSI (Forest Survey of India), The India State of Forest Report 2015

[12] Gamble J.S. (1896). The Bambuseae of British India. Annals of Royal Botanic Garden, Vol. VII, Calcutta: Printed at the Bengal Secretariat Press,

[13] Pandey AK, Ojha V, Choubey SK. Development and shelf-life evaluation of value added edible products from bamboo shoots. Am J Food Technol. 7:363-371, 2012.

[14] Raja Rishi R, Barthakur N.D, Borah R.K, Kumar R, Pandey S, Pest problems of some commercially important bamboo species of Assam; International Journal for life Sciences and Educational Reseatrch, Vol2 (4):113-120, 2014.

[15] Rawat B.S. Flowering of Bamboos. Indian Forester, 113: 760-761, 1987.

[16] S. Tewari, Ratan Lal Banik, R. Kaushal, D.R. Bhardwaj, O.P. Chaturvedi and Anand Gupta, "Bamboo Based Agroforestry Systems"Bamboos of India published by Enviscentre on Forestry, 2015.

[17] Seethalakshmi K. K. and Kumar M.M.S. Bamboos of India; A compendium. Bamboo information center, Kerala Forest Research Institute, Peechi and International Network for Bamboos and Rattan, Beijing, 1998.

[18] Salam K and Deka N training manual on "Nursery raising, commercial plantation, Preservation and primary processing of bamboo"Cane and Bamboo Technology Centre, Guwahati,edited by S. N. Kalita, 2007.

[19] Singh KA, Prospects of edible bamboo shoot farming in North-East India. ICAR News (Jan-Mar): 5-8. 2002.

[20] Tripathi Y.C Bamboo Identification, ARCBR / Technical Report-02), 2008. 